\title{
PENGARUH KEPEMIMPINAN TERHADAP KINERJA PEGAWAI BAGIAN REKAM MEDIS RSUD dr.H.ABDUL MOELOEK PROVINSI LAMPUNG
}

\author{
Miyana $^{(1)}$, Fahrizi $^{(2)}$, Maria Elina ${ }^{(3)}$ \\ Fakultas Ekonomi Universitas Sang Bumi Ruwa Jurai \\ miyana258@gmail.com,fahrizi@fe.saburai.ac.id,maria.elina@fe.saburai.ac.id
}

\begin{abstract}
Abstrak. Kepemimpinan merupakan inti dari pada manajemen dan organisasi, sehingga keberadaan dan fungsi setiap pimpinan diharapkan dapat menjadi motor penggerak bagi setiap kegiatan, orang-orang dan fasilitas kerja yang ada dalam organisasi pemerintah. Melalui kepemimpinan yang baik dari seorang atasan diharapkan dapat menggerakkan motif, keinginan kerja dan perilaku setiap pegawai sehingga segenap pegawai yang ada dapat diarahkan dan digerakkan kepada tujuan yang hendak dicapai. Tujuan penelitian untuk mengetahui pengaruh kepemimpinan terhadap kinerja pegawai Bagian Rekam Medis RSUD dr.H.Abdul Moeloek Provinsi Lampung. Objek penelitian ini adalah seluruh pegawai pada Bagian Rekam Medis RSUD dr.H.Abdul Moeloek Provinsi Lampung yang berjumlah 42 orang pegawai. Uji Hipotesis melalui uji $\mathrm{t}$ (test) diperoleh nilai $\mathrm{t}_{\text {hitung }}$ Kepemimpinan terhadap kinerja pegawai sebesar 5,247, dan hasil $\mathrm{t}_{\text {hitung }}=5,247>\mathrm{t}_{\text {tabel }}=2,024$. Hasil ini menunjukkan bahwa terdapat pengaruh kepemimpinan terhadap kinerja pegawai pada bagian rekam medis RSUD dr.H.Abdul Moeloek Provinsi Lampung.
\end{abstract}

Kata kunci: Kepemimpinan, Kinerja, Pegawai, Pimpinan.

\section{PENDAHULUAN}

Sumber daya manusia merupakan aset perusahaan yang paling unik, paling rentan, paling murni dan sukar diperkirakan. Setiap pegawai memiliki seperangkat latar belakang yang berbeda, yang akan mempengaruhi harapan masing-masing dan pada gilirannya akan mempengaruhi dinamika hubungan antara manusia dan organisasi perusahaan.

Sebuah instansi harus didukung sumber daya manusia yang cakap, karena sumber daya manusia sangat berperan dalam menjalankan usaha atau kegiatan di dalam instansi tersebut (Soekidjo Notoatmodjo, 2003). Merupakan suatu pertanyaan yang terus-menerus muncul dan selalu dihadapi para pimpinan unit kerja, ada pegawai mempunyai kemampuan dan keterampilan serta semangat kerja yang sesuai dengan harapan organisasi, adakalanya pegawai yang mempunyai kemampuan dan keterampilan tetapi tidak mempunyai semangat kerja yang tinggi, sehingga kedisiplinan dalam bekerja tidak sesuai dengan harapan organisasi.

Faktor kinerja pegawai dalam menjalankan unit usaha organisasi merupakan salah satu dasar dan kunci pokok bagi organisasi untuk secara dinamis dan terus berkembang dalam usahanya. Kinerja pegawai akan mempengaruhi tingkat produktivitas organisasi sehingga setiap pekerjaan yang dilakukan pegawai dalam mendukung pencapaian tujuan organisasi dapat tercapai secara efektif dan efisien.

Salah satu faktor yang berperan dalam pengembangan sikap dan kemampuan pegawai dalam organisasi sehingga mampu menghasilkan kinerja yang baik dalam bekerja adalah keberhasilan kepala/ pimpinan untuk menjalankan secara baik fungsi kepemimpinannya. Kepemimpinan merupakan inti dari pada manajemen dan organisasi, sehingga keberadaan dan fungsi setiap pimpinan diharapkan dapat menjadi 
motor penggerak bagi setiap kegiatan, orang-orang dan fasilitas kerja yang ada dalam organisasi pemerintah.

Perkembangan kepemimpinan tidak hanya diperhatikan oleh organisasi swasta, melainkan organisasi pemerintah juga dalam meningkatkan kinerja pegawai. Adapun organisasi pemerintah satu diantaranya adalah RSUD dr. H. Abdul Moeloek Provinsi Lampung. RSUD dr. H. Abdul Moeloek Provinsi Lampung merupakan Rumah Sakit Pusat Rujukan di Provinsi Lampung dengan type B Pendidikan. Dalam memberikan pelayanan kepada pasien RSUD dr. H. Abdul Moeloek Provinsi Lampung menerima berbagai macam karakteristik pasien serta diagnosa medis maupun keperawatan yang beragam. Bagian Rekam Medis adalah salah satu bagian organisasi yang sangat penting dalam menunjang operasional pelayanan di Rumah Sakit.

Adapun tugas pokok Bagian Rekam Medis sebagai ujung tombak penyediaan berkas rekam medis yang lengkap dan aktual adalah pengelolaan berkas rekam medis sesuai dengan kebijaksanaan yang ditetapkan oleh Gubernur Kepala Daerah berdasarkan peraturan perundangan undangan yang berlaku. Berdasarkan data yang diperoleh dapat diketahui bahwa program Bagian Rekam Medis RSUD dr.H.Abdul Moeloek Provinsi Lampung belum tercapai secara baik. Hal ini menunjukkan belum optimalnya kinerja pegawai dalam menjalankan tugas, seperti pegawai belum menyelesaikan tugas yang dibebankan oleh pimpinan secara tepat waktu. Tingkat disiplin pegawai dalam bekerja belum seluruhnya baik. Masih terdapat pegawai yang datang terlambat dan pegawai tidak mengikuti kegiatan apel pagi yang dilakukan secara rutin. Kondisi tersebut diantaranya adalah disebabkan oleh masih kurangnya bimbingan dan pengarahan pimpinan serta ketegasan pimpinan untuk mengendalikan pegawai dalam bekerja.

Pimpinan merupakan orang yang paling bertanggung jawab dalam pencapaian program kerja atau rencana sebuah lembaga. Oleh sebab itu pimpinan melalui fungsi kepemimpinannya diharapkan dapat menggerakkan pegawai hingga dapat tunduk dan patuh kepada perintah-perintahnya. Pimpinan juga harus mampu mendorong motivasi kerja setiap pegawai yang ada sehingga tingkat semangat dan gairah pegawai dalam bekerja semakin meningkat.

Berdasarkan beberapa hal yang disebutkan, maka penulis tertarik meneliti lebih lanjut dengan judul: "Pengaruh Kepemimpinan Terhadap Kinerja Pegawai Bagian Rekam Medis RSUD dr.H.Abdul Moeloek Provinsi Lampung".

\section{KAJIAN TEORI}

\section{Pengertian Kepemimpinan}

Kepemimpinan merupakan kemampuan mempengaruhi aktivitas orang lain melalui komunikasi, baik individual maupun kelompok kearah pencapaian tujuan (Anoraga, 2004). Menurut Hasibuan (2002) kepemimpinan adalah cara seorang pemimpin mempengaruhi perilaku bawahan, agar mau bekerja sama dan bekerja secara produktif untuk mencapai tujuan organisasi. Kepemimpinan atau leadership merupakan ilmu terapan dari ilmu-ilmu sosial, sebab prinsip-prinsip dan rumusannya diharapkan dapat mendatangkan manfaat bagi kesejahteraan manusia.

George R. Terry menyampaikan kepemimpinan sebagai aktivitas untuk mempengaruhi orang-orang agar diarahkan mencapai tujuan organisasi (Thoha, 2003). Robbins (2012) menyampaikan bahwa "Kepemimpinan adalah apa yang pemimpin 
lakukan. Itu adalah proses memimpin kelompok dan mempengaruhinya untuk mencapai tujuan".

\section{Fungsi Kepemimpinan}

Fungsi kepemimpinan berhubungan dengan situasi sosial dalam kehidupan kelompok atau organisasi dimana fungsi kepemimpinan harus diwujudkan dalam interaksi antar individu. Menurut Rivai (2005) secara operasional fungsi pokok kepemimpinan dapat dibedakan sebagai berikut :

\section{Fungsi Instruktif}

Fungsi ini bersifat komunikasi satu arah. Pemimpin sebagai komunikator merupakan pihak yang menentukan apa, bagaiman, bilamana, dan dimana perintah itu dikerjakan agar keputusan dapat dilaksanakan secara efektif.

2. Fungsi konsultatif

Fungsi ini bersifat komunikasi dua arah. Konsultasi itu dimaksudkan untuk memperoleh masukan berupa umpan balik untuk memperbaiki dan menyempurnakan keputusan-keputusan yang telah ditetapkan dan dilaksanakan.

3. Fungsi Partisipasi

Dalam menjalankan fungsi ini pemimpin berusaha mengaktifkan orangorang yang dipimpinnya, baik dalam keikut sertaan mengambil keputusan maupun dalam melaksanakannya.

4. Fungsi Delegasi

Fungsi ini dilaksanakan dengan memerikan pelimpahan wewenang membuat atau menetapkan keputusan, baik melalui persetujuan maupun tanpa persetujuan dari pimpinan.

5. Fungsi Pengendalian

Fungsi pengendalian bermaksud bahwa kepemimpinan yang sukses atau efektif mampu mengatur aktivitas anggotanya secara terarah dan dalam koordinasi yang efektif sehingga memungkinkan terciptanya tujuan bersama secara maksimal.

\section{Pengertian Kinerja}

Kinerja merupakan perilaku organisasi yang secara langsung berhubungan dengan produksi barang atau penyampaian jasa. Informasi tentang kinerja organisasi merupakan suatu hal yang sangat penting digunakan untuk mengevaluasi apakah proses kinerja yang dilakukan organisasi selama ini sudah sejalan dengan tujuan yang diharapkan atau belum.

Menurut Guritno dan Waridin (2005) kinerja merupakan perbandingan hasil kerja yang dicapai oleh karyawan dengan standar yang telah ditentukan. Sedangkan menurut Hakim (2006) mendefinisikan kinerja sebagai hasil kerja yang dicapai oleh individu yang disesuaikan dengan peran atau tugas individu tersebut dalam suatu perusahaan pada suatu periode waktu tertentu, yang dihubungkan dengan suatu ukuran nilai atau standar tertentu dari perusahaan dimana individu tersebut bekerja. Kinerja merupakan perbandingan hasil kerja yang dicapai oleh pegawai dengan standar yang telah ditentukan (Masrukhin dan Waridin, 2004).

Berdasarkan pengertian kinerja dari beberapa pendapat diatas, kinerja merupakan perbandingan hasil kerja yang dicapai oleh karyawan dengan standar yang telah ditentukan. Kinerja juga berarti hasil yang dicapai oleh seseorang, baik kuantitas maupun kualitas dalam suatu organisasi sesuai dengan tanggung jawab yang dberikan kepadanya.

\section{Indikator Kinerja}

Indikator kinerja merupakan aspekaspek yang menjadi ukuran dalam menilai kinerja. Adapun mengenai indikator yang menjadi ukuran kinerja menurut Robert L. Mathis (2006) adalah sebagai berikut : 
1) Kuantitas

Merupakan jumlah yang dihasilkan, dinyatakan dalam istilah seperti jumlah unit, jumlah siklus aktivitas yang diselesaikan karyawan, dan jumlah aktivitas yang dihasilkan

2) Kualitas

Kualitas kerja diukur dari persepsi karyawan terhadap kualitas pekerjaan yang dihasilkan serta kesempurnaan tugas terhadap ketrampilan dan kemampuan karyawan.

3) Ketepatan waktu

Ketepatan waktu diukur dari persepsi karyawan terhadap suatu aktivitas yang diselesaikan di awal waktu sampai menjadi output.

4) Kehadiran

Kehadiran karyawan di perusahaan baik dalam masuk kerja, pulang kerja, izin, maupun tanpa keterangan yang seluruhnya mempengaruhi kinerja karyawan itu.

5) Kemampuan bekerjasama

Kemampuan bekerja sama adalah kemampuan seseorang tenaga kerja untuk bekerja sama dengan orang lain dalam menyelesaikan suatu tugas dan pekerjaan yang telah ditetapkan sehingga mencapai daya guna dan hasil guna yang sebesar-besarnya.

\section{METODE PENELITIAN}

\section{Objek Penelitian}

Objek penelitian ini adalah seluruh pegawai pada Bagian Rekam Medis RSUD dr.H.Abdul Moeloek Provinsi Lampung yang berjumlah 42 orang pegawai. Penelitian dilakukan dari bulan Juni sampai dengan Agustus tahun 2017.

\section{Metode dan Teknik Pengumpulan Data}

Dalam penelitian ini jenis data yang diperlakukan adalah : a. Data Primer

Data primer merupakan data dasar yang akan diperoleh langsung tanpa perantara orang atau lembaga lain sebagai pihak ketiga. Data primer ini diperoleh dengan wawancara melalui responden dengan menggunakan daftar pertanyaan.

\section{b. Data Sekunder}

Data skunder merupakan data yang diperoleh melalui orang lain yang berhubungan dengan permasalahan yang dipecahkan. Data sekunder ini diperoleh melalui cara studi dokumenter yaitu mengumpulkan dan mempelajari brosurbrosur serta dokumen organisasi.

Langkah-langkah pengumpulan data yang penulis lakukan dengan mengadakan penelitian lapangan yaitu Penelitian yang dilakukan pada Kantor Bagian Rekam Medis RSUD dr.H.Abdul Moeloek Provinsi Lampung, adapun teknik yang digunakan dalam pengumpulan data adalah dengan :

1. Observasi, yaitu mengadakan survey atau pengamatan langsung kelokasi penelitian.

2. Interview atau wawancara, yaitu mengadakan tanya jawab langsung dengan pegawai pada Kantor Sekretariat DPRD Kabupaten Pesawaran.

3. Dokumentasi, yaitu mengumpulkan dan mencatat dokumentasi yang relevan.

4. Kuisioner, yaitu membuat pertanyaan yang berhubungan dengan varibael penelitian.

\section{Sampel dan Populasi}

Sehubungan dengan populasi pegawai pada Bagian Rekam Medis RSUD dr.H.Abdul Moeloek Provinsi Lampung berjumlah 42 orang atau dibawah 100 orang, maka yang menjadi sampel penelitian, yaitu sebanyak 42 orang pegawai. Untuk menghindari bias penelitian 
maka Kepala Sub Bagian Rekam Medis dan peneliti tidak diikutsertakan dalam penelitian sehingga jumlah sampel secara keseluruhan sebanyak 40 orang pegawai.

\section{Metode Analisis Data}

Analisis kualitatif adalah analisis yang menggambarkan secara rinci, dengan interpretasi terhadap data yang diperoleh melalui pendekatan teoritis. Dalam hal ini adalah untuk menyederhanakan data ke dalam bentuk yang lebih mudah dibaca dan diinterpretasikan melalui pendekatan teori, kemudian dideskripsikan atau dijelaskan. Analisis statistik deskriptif dalam penelitian ini akan dilakukan dengan mendeskripsikan semua data dari semua variabel dalam bentuk distribusi frekuensi.

Data yang diperoleh dari hasil angket untuk masing-masing variabel menggunakan Skala Likert, dimana alternatif jawaban responden diberikan skor 1 sampai dengan 5, selanjutnya nilai-nilai dari jawaban responden dijumlahkan berdasarkan bobot nilai.

Analisis kuantitatif ialah metode analisis dengan angka-angka yang dapat dihitung maupun diukur, dan dalam prosesnya menggunakan alat bantu statistik. Statistik sendiri merupakan cara-cara ilmiah yang digunakan untuk mengumpulkan, mengolah, menganalisis, dan menginterpretasikan data berupa angkaangka, kemudian menarik kesimpulan atas data tersebut, dimana data tersebut disajikan dalam bentuk tabel, grafik, atau gambar (Algifari, 2003).

Persamaan Regresi Linear Sederhana menentukan persamaan regresi linear sederhana untuk X :

$$
Y=a+b X+e
$$

Keterangan:

$$
\mathrm{Y}=\text { Kinerja pegawai }
$$

$$
\begin{aligned}
& \mathrm{a}=\text { Konstanta } \\
& \mathrm{b}=\text { Koefisien regresi } \mathrm{X} \\
& \mathrm{X}=\text { Kepemimpinan } \\
& \mathrm{e}=\text { Faktor kesalahan }
\end{aligned}
$$

Untuk mengetahui besarnya pengaruh, penghitungan koefisien korelasi tersebut kemudian dilanjutkan dengan Rumus Koefisien Determinasi atau Koefisien Penentu (KP):

$$
K P=(r)^{2} x 100 \%
$$

Untuk menguji secara hipotesis secara parsial digunakan Uji t dengan rumus :

$$
t_{\text {hitung }}=\frac{r \sqrt{N-2}}{\sqrt{1-r^{2}}}
$$

Keterangan:

$$
\begin{array}{ll}
\mathrm{t}_{\text {hitung }} & =\text { Nilai } \mathrm{t} \\
\mathrm{r} & =\text { Koefisien Korelasi } \\
\mathrm{N} & =\text { Jumlah responden }
\end{array}
$$

Kriteria untuk Uji $\mathrm{t}$ adalah sebagai berikut :

a) Jika $t_{\text {hitung }}>t_{\text {tabel }}$ maka Ha diterima dan Ho ditolak.

b) Jika $t_{\text {hitung }} \leq \mathrm{t}_{\text {tabel }}$ maka Ha ditolak dan Ho diterima.

\section{HASIL DAN PEMBAHASAN}

\section{Uji Validitas}

Uji validitas dilakukan untuk mengetahui valid atau tidaknya pernyataanpernyataan yang akan digunakan dan atau dapat tidaknya digunakan sebagai alat ukur penelitian.

Berdasarkan pengujian validitas dari masing-masing variabel yaitu 15 pernyataan utuk variabel Independent $(\mathrm{X})$ dan variabel (Y) jawaban responden telah memiliki validitas yang cukup baik. Hasil keseluruhan dari pengujian validitas terhadap instrumen pernyataan untuk 
variabel Kepemimpinan (X) dan variabel kinerja pegawai (Y) dapat dilihat pada Tabel 1. Dan Tabel 2.

Tabel 1. Uji Validitas Kepemimpinan (X)

\begin{tabular}{cccc}
$\begin{array}{c}\text { Item } \\
\text { Pernyatan }\end{array}$ & $\mathrm{r}_{\text {tabel }}$ & $\begin{array}{c}\text { Koefesien } \\
\mathrm{r}_{\text {hitung }}\end{array}$ & Keterangan \\
\hline 1 & 0,514 & 0,722 & Valid \\
3 & 0,514 & 0,576 & Valid \\
4 & 0,514 & 0,564 & Valid \\
5 & 0,514 & 0,669 & Valid \\
6 & 0,514 & 0,562 & Valid \\
7 & 0,514 & 0,561 & Valid \\
8 & 0,514 & 0,699 & Valid \\
9 & 0,514 & 0,704 & Valid \\
10 & 0,514 & 0,611 & Valid \\
11 & 0,514 & 0,748 & Valid \\
12 & 0,514 & 0,597 & Valid \\
13 & 0,514 & 0,748 & Valid \\
14 & 0,514 & 0,739 & Valid \\
15 & 0,514 & 0,611 & Valid \\
\hline
\end{tabular}

Berdasarkan Tabel 1. dapat diketahui bahwa seluruh item skor pernyataan tentang Kepemimpinan memiliki nilai $\mathrm{r}$ hitung lebih besar dari $r_{\text {tabel }}=0,514$. Dengan nilai $r$ hitung $=0,561-0,748$. Dengan demikian dapat dikatakan bahwa keseluruhan item pernyataan mengenai Kepemimpinan tersebut valid dan dapat digunakan sebagai alat ukur penelitian.

Berdasarkan Tabel 2. dapat diketahui bahwa seluruh item skor pernyataan tentang Kinerja Pegawai memiliki nilai $r$ hitung dengan nilai $r$ hitung $=0,536-0,862$ lebih besar dari $r$ tabel $=0,514$. Dengan demikian dapat dikatakan bahwa keseluruhan item pertanyaan mengenai kinerja pegawai tersebut valid dan dapat digunakan sebagai alat ukur penelitian.

Tabel 2. Uji Validitas Kinerja Pegawai (Y)

\begin{tabular}{cccc}
$\begin{array}{c}\text { Item } \\
\text { Pernyataan }\end{array}$ & $\mathrm{r}_{\text {tabel }}$ & $\begin{array}{c}\text { Koefesien } \\
\mathrm{r}_{\text {hitung }}\end{array}$ & Keterangan \\
1 & 0,514 & 0,765 & Valid \\
2 & 0,514 & 0,821 & Valid \\
3 & 0,514 & 0,772 & Valid \\
4 & 0,514 & 0,830 & Valid \\
5 & 0,514 & 0,577 & Valid \\
6 & 0,514 & 0,837 & Valid \\
7 & 0,514 & 0,600 & Valid \\
8 & 0,514 & 0,662 & Valid \\
9 & 0,514 & 0,536 & Valid \\
10 & 0,514 & 0,862 & Valid \\
11 & 0,514 & 0,651 & Valid \\
12 & 0,514 & 0,575 & Valid \\
13 & 0,514 & 0,738 & Valid \\
14 & 0,514 & 0,591 & Valid \\
15 & 0,514 & 0,718 & Valid \\
\hline
\end{tabular}

\section{Uji Reliabelitas Data}

Uji realibilitas digunakan untuk mengetahui layak tidaknya data responden yang digunakan dalam penelitian ini. Instrumen dapat dikatakan reliabel bila memiliki koefisien kehandalan reliabilitas sebesar 0,6 atau lebih. Dari hasil Uji Reliabilitas diperoleh nilai alpha Kepemimpinan (X) sebesar 0,920 dan dapat disimpulkan bahwa kuesioner yang digunakan dalam penelitian ini dinyatakan reliabel karena alpha-nya sebesar 0,920 > 0,60. Nilai alpha kinerja pegawai (Y) sebesar 0,938 dan atas hasil ini dapat disimpulkan bahwa kuesioner yang digunakan dalam penelitian ini dinyatakan reliabel karena nilai alpha-nya sebesar $0,938>0,60$. Ini berarti alat ukur yang digunakan dalam penelitian ini sudah memiliki kemampuan untuk memberikan hasil pengukuran yang konsisten dalam mengukur gejala yang sama.

\section{Analisis Kuantitatif}

Berdasarkan hasil perhitungan tingkat korelasi antar variabel diperoleh besarnya 
tingkat korelasi antara variabel Kepemimpinan (X) dengan variabel kinerja pegawai (Y) pada Bagian Rekam Medis RSUD dr.H.Abdul Moeloek Provinsi Lampung adalah sebesar 0,648. Jika dikonsultasikan dengan tabel Interpretasi Koefesien Korelasi maka tingkat korelasi Kepemimpinan (X) dengan variabel Kinerja Pegawai (Y) pada Bagian Rekam Medis RSUD dr.H.Abdul Moeloek Provinsi Lampung dalam kategori korelasi "kuat", yakni terletak pada $(0,600-0,799)$.

Koefisien Determinasi $(\mathrm{KD})=\mathrm{R} 2=$ $0,6482=0,420 \times 100 \%=42,0 \%$. Dapat disimpulkan bahwa variabel Kepemimpinan (X) menjelaskan variasi perubahan terhadap variabel Kinerja Pegawai (Y) pada Bagian Rekam Medis RSUD dr.H.Abdul Moeloek Provinsi Lampung sebesar 42,0\%, sedangkan sisanya dijelaskan oleh faktor lain yang tidak dikaji dalam penelitian ini.

Berdasarkan hasil Uji t didapat nilai $\mathrm{t}$ hitung $=5,247$. Apabila dibandingkan dengan $\mathrm{t}$ tabel pada taraf signifikan yaitu 2,024 , maka thitung $=5,247>\mathrm{t}$ tabel $=$ 2,024, sehingga dapat disimpulkan bahwa ; Ha yang menyatakan terdapat pengaruh variabel Kepemimpinan (X) terhadap variabel Kinerja Pegawai (Y) pada Bagian Rekam Medis RSUD dr.H.Abdul Moeloek Provinsi Lampung dapat diterima. Jadi variabel Kepemimpinan (X) berpengaruh terhadap variabel Kinerja Pegawai (Y).

Persamaan regresi antara variabel Kepemimpinan (X) terhadap variabel kinerja pegawai (Y) Pada Bagian Rekam Medis RSUD dr.H.Abdul Moeloek Provinsi Lampung adalah $\mathrm{Y}=24,769+0,571 \mathrm{X}$, yang artinya setiap kenaikan satu point daripada variabel Kepemimpinan akan diikuti oleh naiknya variabel Kinerja Pegawai 0,571 point.

Kepemimpinan adalah bagaimana seorang pemimpin melaksanakan fungsi kepemimpinannya dan bagaimana ia dilihat oleh mereka yang berusaha dipimpinnya atau mereka yang mungkin sedang mengamati dari luar. Kepemimpinan merupakan inti dari pada manajemen dan organisasi, sehingga keberadaan dan fungsi setiap pimpinan diharapkan dapat menjadi motor penggerak bagi setiap kegiatan, orang-orang dan fasilitas kerja yang ada dalam organisasi pemerintah. Melalui kepemimpinan yang baik dari seorang atasan diharapkan dapat menggerakkan motif, keinginan kerja dan perilaku setiap pegawai sehingga segenap pegawai yang ada dapat diarahkan dan digerakkan kepada tujuan yang hendak dicapai.

\section{KESIMPULAN DAN SARAN}

\section{Kesimpulan}

Berdasarkan analisis data diperoleh kesimpulan bahwa terdapat pengaruh Kepemimpinan terhadap Kinerja pegawai pada Bagian Rekam Medis RSUD dr.H.Abdul Moeloek Provinsi Lampung, hal ini terbukti dari Uji Hipotesis melalui uji $\mathrm{t}$ (test) diperoleh nilai thitung Kepemimpinan terhadap kinerja pegawai sebesar 5,247, dan hasil thitung $=5,247>t_{\text {tabel }}$ $=2,024$. Hasil ini menunjukkan bahwa terdapat pengaruh Kepemimpinan terhadap Kinerja pegawai Pada Bagian Rekam Medis RSUD dr.H.Abdul Moeloek Provinsi Lampung.

\section{Saran}

Adapun saran yang diajukan peneliti adalah sebagai berikut :

1. Gaya kepemimpinan yang perlu mendapatkan perhatian agar lebih baik lagi adalah memperbaiki pada aspek perlunya pemimpin melakukan koordinasi dengan bawahan dalam menyelesaikan pekerjaan, pembagian tugas yang sesuai dengan kompetensi bawahan, serta mendelegasikan tugas kepada bawahan yang kompeten dibidangnya. Dengan melakukan 
koordinasi yang baik serta penugasan yang sesuai dengan kompetensi bawahan maka dapat memudahkan pemimpin dalam mengembangkan gaya kepemimpinan yang lebih baik.

2. Kinerja pegawai sebaiknya yang perlu dibenahi adalah pada peningkatan kualitas hasil pekerjaan, dengan demikian diharapkan kinerja pegawai akan menjadi lebih baik lagi.

\section{DAFTAR PUSTAKA}

Anoraga, Pandji. 2004. Manajemen Bisnis, Cetakan Ketiga. Jakarta: Rineka Cipta.

Arikunto, Suharsimi. 2006. Prosedur Penelitian Suatu Pendekatan dan Praktek, edisi Revisi VII. Jakarta: Rineka Cipta.

Fydayeen, Akhmad. 2016. Pengaruh Kepemimpinan Dan Motivasi Kerja Terhadap Kinerja Pegawai Bagian Hukum Sekretariat Daerah Kota Samarinda. eJournal Administrative Reform. Vol.04. No.3. 2016. Pp. 735-747.

Guritno, Bambang., dan Waridin. 2005. Pengaruh Persepsi Karyawan Mengenai Perilaku Kepemimpinan, Kepuasan Kerja, dan Motivasi Terhadap Kinerja. JRBI. Vol.01. No.01. Pp. 63-74.

Hakim, A. 2006. Analisis pengaruh motivasi, komitmen organisasi dan iklim organisasi terhadap kinerja pegawai pada dinas perhubungan dan telekomunikasi Provinsi Jawa Tengah. Jurnal riset dan bisnis Indononesia. Vol.03. No.02. Pp. 165-180.

Hasibuan. 2002. Manajemen Sumber Daya Manusia. Jakarta: Bumi Aksara.
Kartono, Kartini. 2011. Pemimpin dan Kepemimpinan. Jakarta: Rajawali Pers.

Masrukhin dan Waridin. 2004. Pengaruh Motivasi Kerja, Kepuasan Kerja, Budaya Organisasi Dan Kepemimpinan Terhadap Kinerja Pegawai. EKOBIS. Vol.07. No.02. Pp. 197-209.

Mathis, R.L dan Jackson. 2006. Manajemen Sumber Daya Manusia. Jakarta: Salemba Empat.

Rivai, Veithzal dan Basri. 2005. Performance Appraisal: Sistem Yang Tepat Untuk Menilai Kinerja Karyawan Dan Meningkatkan Daya Saing Perusahaan. Jakarta: PT Rajagrafindo Persada.

Robbins, Stephen. P. 2012. Perilaku Organisasi. Edisi Bahasa Indonesia. Jakarta: PT.Indeks Kelompok Gramedia.

Sugiyono . 2008. Statistik Untuk Penelitian. Bandung: CV Alfabeta.

Terry. George R. 2006. Human Resources. Jakarta: PT. Pustaka Binaman Pressindo.

Toha, Miftah (2003). Perilaku Organisasi: Konsep dan Aplikasi. Jakarta: Rajawali Pers

Yuwalliatin, Sitty. 2006. Pengaruh Budaya Organisasi, Motivasi Dan Komitmen Terhadap Kinerja Serta Pengaruhnya Terhadap Keunggulan Kompetitif Dosen UNISULA Semarang. EKOBIS. Vol.07. No.02. Pp. 241-256. 